\title{
Bifunctional dendrons for multiple carbohydrate presentation via carbonyl chemistry
}

\author{
Davide Bini, Francesco Nicotra and Laura Cipolla*
}

\author{
Letter \\ Address: \\ Department of Biotechnology and Biosciences, University of \\ Milano-Bicocca, Piazza della Scienza 2, 20126 Milano, Italy \\ Email: \\ Laura Cipolla* - laura.cipolla@unimib.it \\ * Corresponding author \\ Keywords: \\ bis-MPA; carbohydrates; dendrons; levulinic acid; multivalency; \\ multivalent glycosystems
}

Beilstein J. Org. Chem. 2014, 10, 1686-1691. doi:10.3762/bjoc. 10.177

Received: 28 February 2014

Accepted: 27 June 2014

Published: 25 July 2014

This article is part of the Thematic Series "Multivalent glycosystems for nanoscience".

Guest Editor: B. Turnbull

(c) 2014 Bini et al; licensee Beilstein-Institut.

License and terms: see end of document.

\begin{abstract}
The synthesis of new dendrons of the generations 0,1 and 2 with a double bond at the focal point and a carbonyl group at the termini has been carried out. The carbonyl group has been exploited for the multivalent conjugation to a sample saccharide by reductive amination and alkoxyamine conjugation.
\end{abstract}

\section{Introduction}

Recognition processes between glycans and their receptors are of paramount relevance in several biological phenomena, both in physiological [1,2] and in pathological [3-5] conditions. These processes can be exploited in diagnostic tools [6,7], in nanobiotechnology applications [8], and in the development of smart biomaterials for regenerative medicine [9-12]. Beside the variation of carbohydrate residues in glycoconjugates, a key issue in the recognition process is their spatial topographical presentation eliciting high affinity recognition events. In order to better understand these phenomena, dendrimers and dendrons have been developed to provide multivalent glycoconjugates $[13,14]$. Here, we propose the synthesis of novel dendron struc- tures which allow for the multivalent conjugation of carbohydrates via carbonyl chemistry.

\section{Results and Discussion}

The heterobifunctional dendrons were designed in order to have bio-orthogonal functional groups at the focal point and at their termini. More specifically, a double bond was placed at the desired matrix as the focal point for further conjugation by thiol-ene chemistry, and carbonyl groups were added at the termini. The carbonyl groups can be exploited for carbohydrate functionalization $[15,16]$ by reductive amination, oxime or hydrazone formation to yield suitably functionalized saccha- 
rides (Figure 1). Given the relevance of L-fucose in mammal oligosaccharides, $\alpha$-L-(2-aminoethyl) fucoside [17] and $\alpha$-O-Lfucopyranosyloxyamine [18] were used as sample monosaccharides for the conjugation of the dendron (Scheme 1).

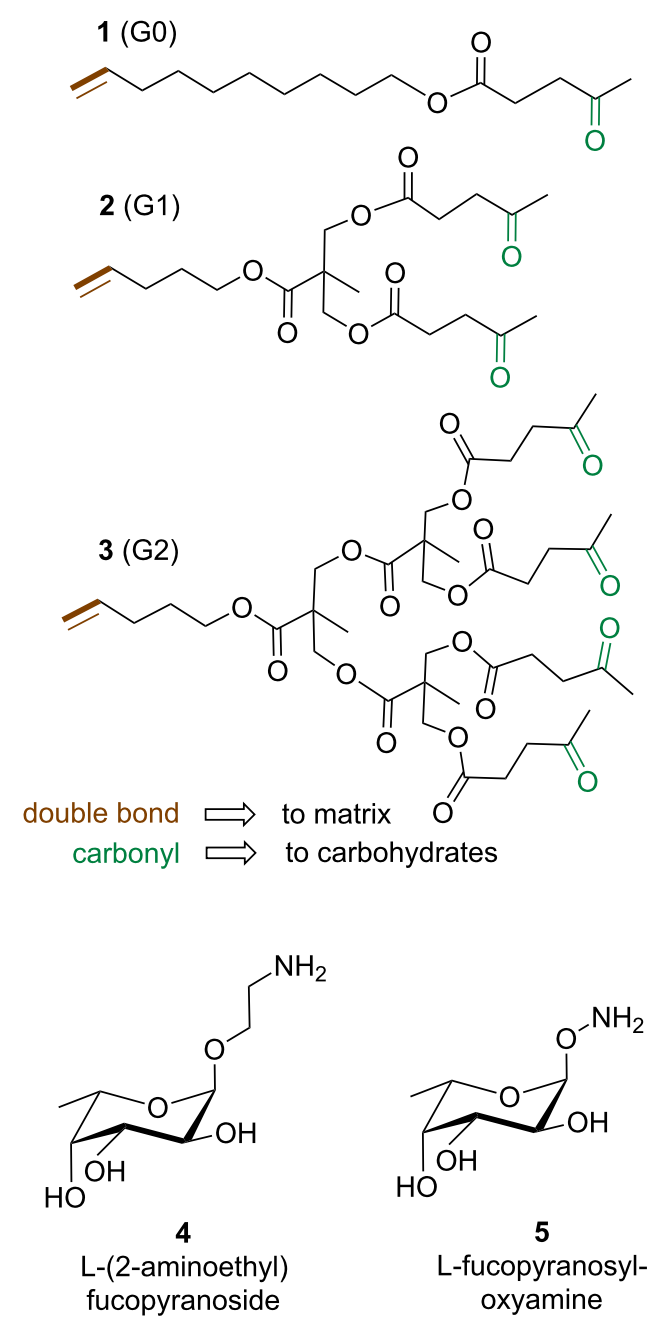

Figure 1: Synthesized G0, G1 and G2 dendrons and functionalized saccharides used for carbonyl conjugation.

\section{Synthesis of dendrons}

Zero, first and second generation heterobifunctional dendrons 1-3 were synthesized starting from 9-decen-1-ol (12) or selected building blocks 13 and $\mathbf{1 4}$ (Scheme 2) [11] by esterification reactions with levulinic acid (15). Building blocks 13 and 14 were synthesized starting from bis-(hydroxymethyl)propionic acid (bis-MPA) and bromo-1-pentene [11] in one and four steps, respectively.

\section{L-Fucose derivatives synthesis}

$\alpha$-L-(2-Aminoethyl) fucopyranoside (4) and $\alpha$-O-L-fucopyranosyloxyamine (5) were synthesized from commercial

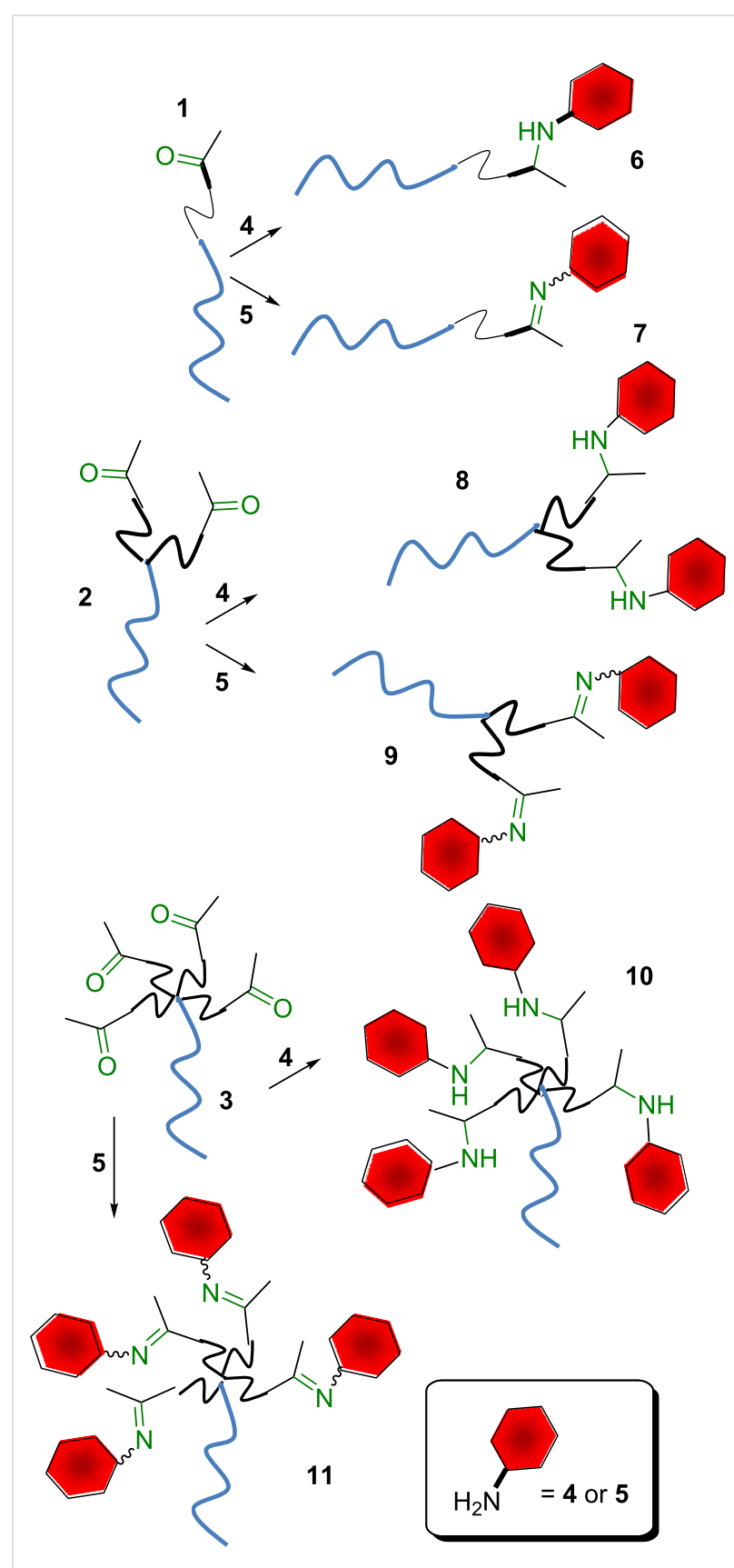

Scheme 1: Schematic depiction of dendron conjugation to saccharides by carbonyl chemistry.

L-fucopyranose in 4 and 5 steps, respectively, as already reported by Flitsch and co-workers [17] and Dumy and co-workers [18].

\section{Dendron conjugation to L-fucose by reduc- tive amination}

$\alpha$-L-(2-Aminoethyl) fucopyranoside (4) was conjugated first to G0 dendron 1 by reductive amination in the presence of $\mathrm{NaCNBH}_{3}$ (Scheme 3). The reaction afforded the desired glyco- 

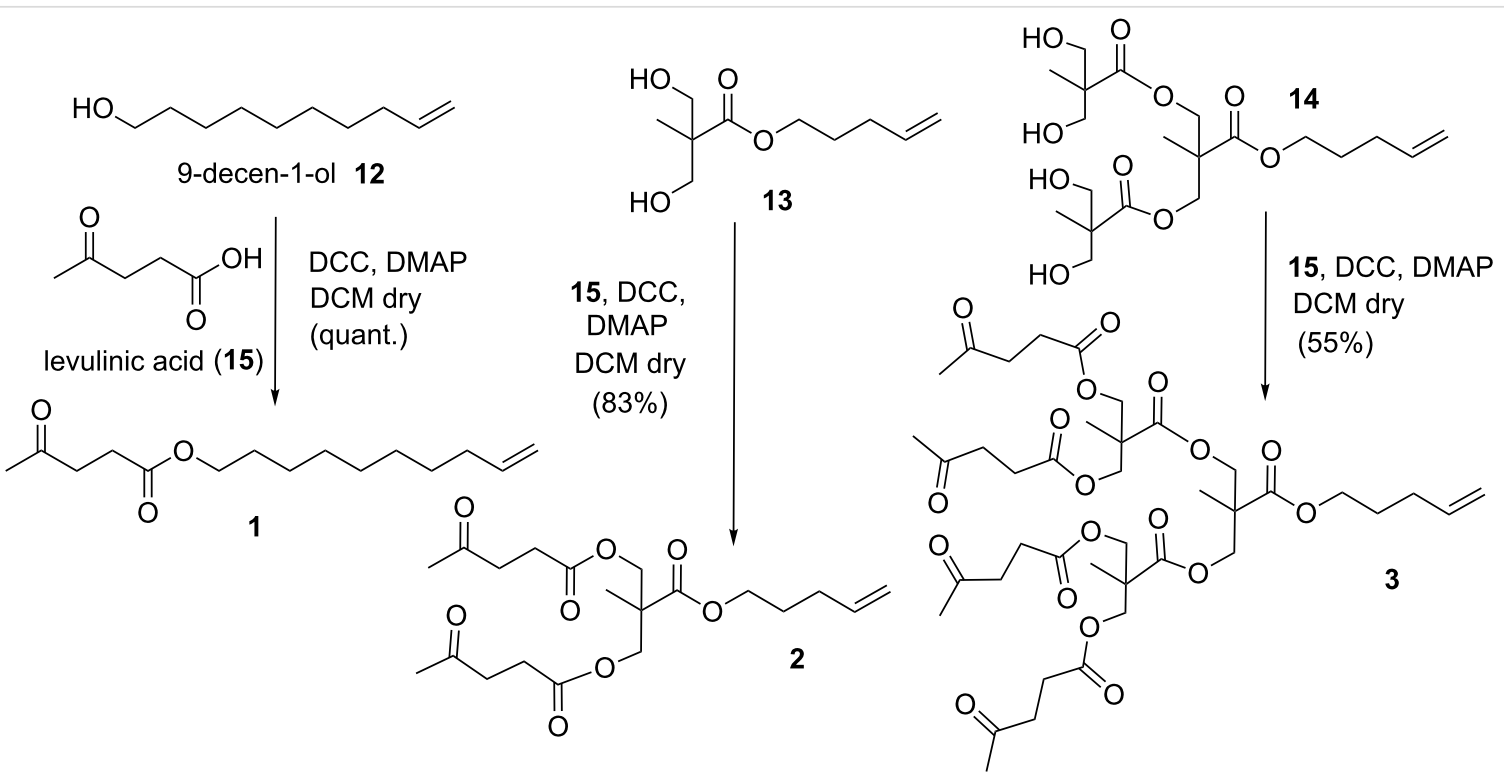

Scheme 2: Synthesis of the dendrons.

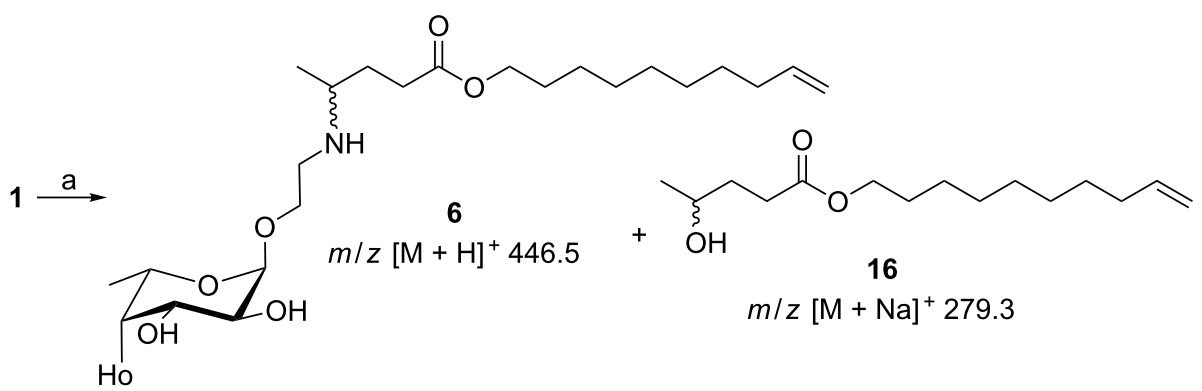

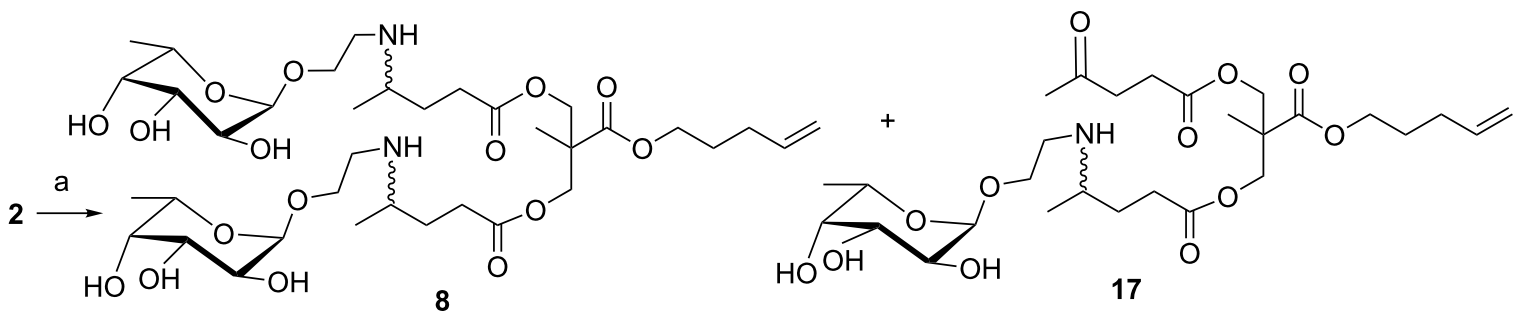

$m / z[\mathrm{M}+\mathrm{H}]^{+} 781.4$

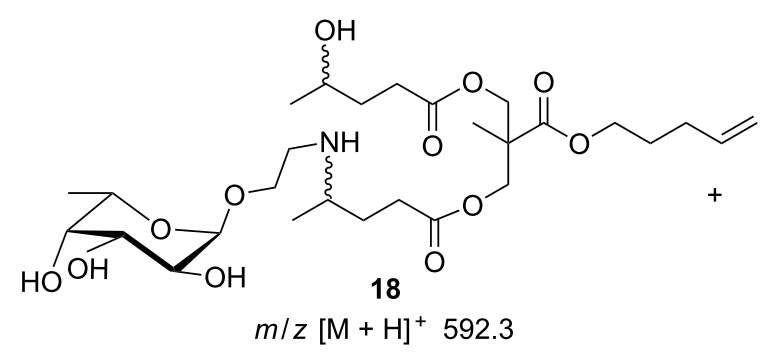<smiles>C=CCCCOC(=O)C(C)(COC(=O)CC[C@H](C)O)COC(=O)CC[C@@H](C)O</smiles>

Scheme 3: Dendron conjugation to fucose moieties by reductive amination. Reagents and conditions: a) 4, $3 \mathrm{M} \mathrm{Na}_{2} \mathrm{SO}_{4}, \mathrm{AcOH} \mathrm{NaCNBH}$, $\mathrm{EtOH}$, $80^{\circ} \mathrm{C}, 6 \mathrm{~h}$. 
sylated dendron 6 in $27 \%$ yield. The very low yield was ascribed to the competing carbonyl reduction to the corresponding alcohol $\mathbf{1 6}$ as a byproduct.

The same reaction on the G1 dendron 2 gave an even more complex mixture of products, identified by mass spectrometry (System Applied Biosystems MDS SCIEX instruments: Q TRAP, LC/MS/MS, turbo ion spray and Q STAR elite nano spray) performed directly on the TLC spots following literature procedures [19]. By mass values, the mixture was composed of the desired fucosylated dendron $\mathbf{8}$ as the minor product together with the monoglycosylated derivatives $\mathbf{1 7}$ and $\mathbf{1 8}$ and the alcohols 19 and 20. In order to reduce the formation of alcohol byproducts, a "milder" reducing agent such as $\mathrm{Na}(\mathrm{AcO})_{3} \mathrm{BH}$ was tried, but without any success.

Given the high extent of byproducts and the low efficiency of the glycoconjugation to the G0 dendron and G1 dendron by reductive amination, we decided to evaluate the possibility to obtain better conjugation yields by oxime ligation. Thus, G0, G1 and G2 dendrons 1-3 were reacted with $\alpha$-O-L-fucopyranosyloxyamine (5) in citrate buffer at pH 3.5 [20] (Scheme 4). Due to the partial hydrophobic nature of the dendrons 1-3 they do not fully dissolve in the buffer, and the solution is not completely clear.

The dendrons 1-3 were reacted overnight at room temperature with $\alpha$-O-L-fucopyranosyloxyamine (5) affording the desired glycoconjugate structures $\mathbf{7 , 9}$ and $\mathbf{1 1}$ in quantitative yields.

\section{Conclusion}

In conclusion, novel G0, G1 and G2 dendrons suitable for glycoconjugation by carbonyl chemistry were synthesized. The conjugation of the saccharide by reductive amination was characterized by a low efficiency. On the other hand, the oxime ligation afforded the glycoconjugated dendrons in quantitative<smiles>C=CCCCCCCCCOC(=O)CCC(C)=NOC1OC2OC1C(O)C(O)C(O)C2C</smiles>

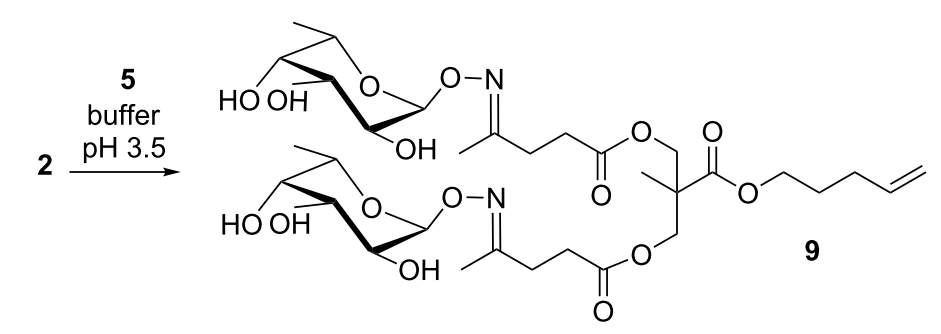

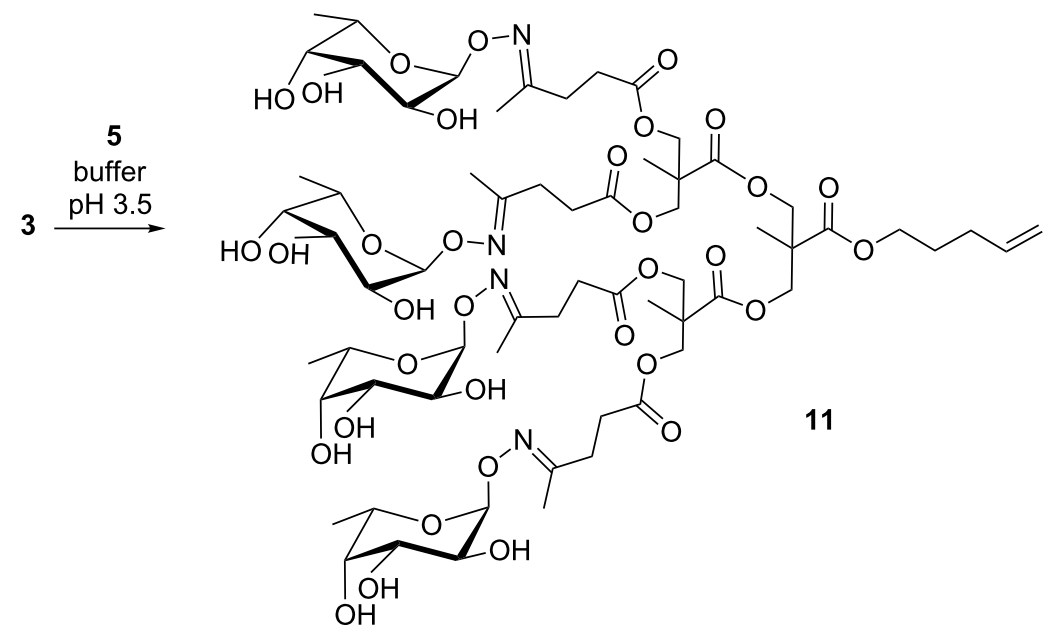


yields. The glycosylated dendrons can be exploited for further chemoselctive thiol-ene reactions with matrices suitably functionalized with thiol groups, i.e., cysteine residues in proteins.

\section{Experimental}

\section{General methods}

All chemicals were purchased from Sigma-Aldrich and used without further purification. All solvents were dried over molecular sieves, for at least $24 \mathrm{~h}$ prior to use, when required. When dry conditions were required, the reaction was performed under an Ar atmosphere. Thin-layer chromatography (TLC) was performed on silica gel 60 F254 coated glass plates (Merck) with UV detection when possible, or spots were visualized by charring with a conc. $\mathrm{H}_{2} \mathrm{SO}_{4} / \mathrm{EtOH} / \mathrm{H}_{2} \mathrm{O}$ solution (10:45:45 v/v/ $\mathrm{v})$, or with a solution of $\left(\mathrm{NH}_{4}\right)_{6} \mathrm{Mo}_{7} \mathrm{O}_{24}(21 \mathrm{~g}), \mathrm{Ce}\left(\mathrm{SO}_{4}\right)_{2}(1 \mathrm{~g})$, conc. $\mathrm{H}_{2} \mathrm{SO}_{4}(31 \mathrm{~mL})$ in water $(500 \mathrm{~mL})$ and then by heating to $110^{\circ} \mathrm{C}$ for $5 \mathrm{~min}$. Flash column chromatography was performed on silica gel 230-400 mesh (Merck). Routine ${ }^{1} \mathrm{H}$ and ${ }^{13} \mathrm{C}$ NMR spectra were recorded on a Varian Mercury instrument at $400 \mathrm{MHz}\left({ }^{1} \mathrm{H}\right)$ and $100.57 \mathrm{MHz}\left({ }^{13} \mathrm{C}\right)$. Chemical shifts are reported in parts per million downfield from TMS as an internal standard, $J$ values are given in Hz. Mass spectra were recorded on System Applied Biosystems MDS SCIEX instruments: Q TRAP, LC/MS/MS, turbo ion spray and Q STAR elite nanospray.

General procedure for levulinic acid condensation (compounds 1-3): To a $0.1 \mathrm{M}$ solution of the appropriate compound dissolved in dry DCM, levulinic acid (1.2 equiv), DMAP ( 0.2 equiv) and DCC ( 1.5 equiv) were added, and the reaction mixture was stirred at room temperature (for 1 to $24 \mathrm{~h}$, depending on the substrate). The precipitates were filtered off and washed with $\mathrm{CH}_{2} \mathrm{Cl}_{2}$. The solvent was evaporated, and the residue was purified by column chromatography on a silica gel column with a suitable eluent. See Supporting Information File 1 for full experimental data.

General procedure for reductive amination reaction (compounds 6,8$)$ : The appropriate dendron (1 equiv) and $\alpha$-L-(2aminoethyl) fucoside (4, 1 equiv) were dissolved in $\mathrm{EtOH}$ ( $0.1 \mathrm{M}$ in respect to 4$)$. $\mathrm{AcOH}$ ( 1 equiv) and $3 \mathrm{M} \mathrm{Na}_{2} \mathrm{SO}_{4}(1 \%$ of solvent volume) were added, and the mixture was heated under reflux for $2 \mathrm{~h} . \mathrm{NaCNBH}_{3}$ (1.5 equiv) was then added, and the reaction was heated under reflux for further $4 \mathrm{~h}$. See Supporting Information File 1 for full experimental data.

General procedure for dendron/ alkoxyamine conjugation (compounds 7, 9, 11): The appropriate dendron (1 equiv) and $\alpha$-O-L-fucopyranosyloxyamine (5, 1 equiv) were dissolved in citrate buffer ( $\mathrm{pH} 3.5,0.1 \mathrm{M}$ in respect to 5) and stirred at room temperature overnight. The mixture was concentrated and the product isolated. See Supporting Information File 1 for full experimental data.

\section{Supporting Information}

\section{Supporting Information File 1}

Experimental part.

[http://www.beilstein-journals.org/bjoc/content/

supplementary/1860-5397-10-177-S1.pdf]

\section{Acknowledgements}

This research was financially supported by the Cariplo Fundation under the grant numbers 2010-0378, 2011-0270 and PRIN 2010L9SH3K.

\section{References}

1. Johnson, J. L.; Jones, M. B.; Ryan, S. O.; Cobb, B. A. Trends Immunol. 2013, 34, 290-298. doi:10.1016/j.it.2013.01.006

2. Moremen, K. W.; Tiemeyer, M.; Nairn, A. V. Nat. Rev. Mol. Cell Biol. 2012, 13, 448-462. doi:10.1038/nrm3383

3. Schedin-Weiss, S.; Winblad, B.; Tjernberg, L. O. FEBS J. 2014, 281, 46-62. doi:10.1111/febs. 12590

4. Kleene, R.; Schachner, M. Nat. Rev. Neurosci. 2004, 5, 195-208. doi:10.1038/nrn1349

5. Ohtsubo, K.; Marth, J. D. Cell 2006, 126, 855-867. doi:10.1016/j.cell.2006.08.019

6. Morais, G. R.; Falconer, R. A.; Santos, I. Eur. J. Org. Chem. 2013, 1401-1410. doi:10.1002/ejoc.201201457

7. Cipolla, L.; Gregori, M.; So, P.-W. Curr. Med. Chem. 2011, 18, 1002-1018. doi:10.2174/092986711794940851

8. Sapsford, K. E.; Algar, W. R.; Berti, L.; Boeneman Gemmill, K.; Casey, B. J.; Oh, E.; Stewart, M. H.; Medintz, I. L. Chem. Rev. 2013, 113, 1904-2074. doi:10.1021/cr300143v

9. Cipolla, L.; Russo, L.; Taraballi, F.; Lupo, C.; Bini, D.; Gabrielli, L.; Capitoli, A.; Nicotra, F. Smart biomaterials: the contribution of glycoscience. In Specialist Periodical Reports, SPR Carbohydrate Chemistry; 2012, Vol. 38, pp. 416-445.

10. Russo, L.; Battocchio, C.; Secchi, V.; Magnano, E.; Nappini, S.; Taraballi, F.; Gabrielli, L.; Comelli, F.; Papagni, A.; Costa, B.; Polzonetti, G.; Nicotra, F.; Natalello, A.; Doglia, S. M.; Cipolla, L. Langmuir 2014, 30, 1336-1342. doi:10.1021/la404310p

11. Bini, D.; Russo, L.; Battocchio, C.; Natalello, A.; Polzonetti, G.; Doglia, S. M.; Nicotra, F.; Cipolla, L. Org. Lett. 2014, 16, 1298-1301. doi:10.1021/ol403476z

12. Du, J.; Yarema, K. J. Adv. Drug Delivery Rev. 2010, 62, 671-682. doi:10.1016/j.addr.2010.01.003

13. Bernardi, A.; Jimenez-Barbero, J.; Casnati, A.; De Castro, C.; Darbre, T.; Fieschi, F.; Finne, J.; Funken, H.; Jaeger, K.-E.; Lahmann, M.; Lindhorst, T. K.; et al. Chem. Soc. Rev. 2013, 42, 4709-4727. doi:10.1039/c2cs35408j

14. Sanchez-Navarro, M.; Rojo, J. Drug News Perspect. 2010, 23 , 557-572. doi:10.1358/dnp.2010.23.9.1437246

15. Paez, J. I.; Martinelli, M.; Brunetti, V.; Strumia, M. C. Polymers 2012, 4, 355-395. doi:10.3390/polym4010355

16. Röglin, L.; Lempens, E. H. M.; Meijer, E. W. Angew. Chem., Int. Ed. 2011, 50, 102-112. doi:10.1002/anie.201003968 
17. Šardzík, R.; Noble, G. T.; Weissenborn, M. J.; Martin, A.; Webb, S. J.; Flitsch, S. L. Beilstein J. Org. Chem. 2010, 6, 699-703. doi:10.3762/bjoc.6.81

18. Duléry, V.; Renaudet, O.; Philouze, C.; Dumy, P. Carbohydr. Res. 2007, 342, 894-900. doi:10.1016/j.carres.2007.02.003

19. St. Hilaire, P. M.; Cipolla, L.; Tedebark, U.; Meldal, M. Rapid Commun. Mass Spectrom. 1998, 12, 1475-1484. doi:10.1002/(SICI)1097-0231(19981030)12:20<1475::AID-RCM365>3. $0 . \mathrm{CO} ; 2-\mathrm{F}$

20. Hudak, J. E.; Yu, H. H.; Bertozzi, C. R. J. Am. Chem. Soc. 2011, 133, 16127-16135. doi:10.1021/ja206023e

\section{License and Terms}

This is an Open Access article under the terms of the Creative Commons Attribution License

(http://creativecommons.org/licenses/by/2.0), which permits unrestricted use, distribution, and reproduction in any medium, provided the original work is properly cited.

The license is subject to the Beilstein Journal of Organic Chemistry terms and conditions:

(http://www.beilstein-journals.org/bjoc)

The definitive version of this article is the electronic one which can be found at: doi:10.3762/bjoc. 10.177 